\title{
Interstitial and Granulomatous lung disease in inflammatory bowel disease patients
}

Eliadou, Elena ; Moleiro, Joana ; Ribaldone, Davide Giuseppe ; et al ; Vavricka, Stephan R

\begin{abstract}
BACKGROUND Interstitial lung (ILD) disease and Granulomatous lung disease (GLD) are rare respiratory disorders that have been associated with inflammatory bowel disease (IBD). Clinical presentation is polymorphic and aetiology is unclear. METHODS This was an ECCO-CONFER project. Cases of concomitant ILD or GLD and IBD or drug induced ILD/GLD were collected. The criteria for diagnosing ILD and GLD were based on definitions from the American Thoracic Society and European Respiratory Society and on the discretion of reporting clinician. RESULTS We identified 31 patients with ILD, majority had ulcerative colitis (UC) $(n=22)$. Drug related ILD was found in $64 \%$ of patients. Twenty five patients $(80.6 \%)$ required hospitalization and 1 required non-invasive ventilation. Causative drug was stopped in all drug related ILD and $87 \%$ of patients received systemic steroids. At follow up 16\% of patients had no respiratory symptoms, $16 \%$ had partial improvement, $55 \%$ had ongoing symptoms, no data in $13 \%$. One patient was referred for lung transplantation and 1 death from lung fibrosis was reported. We also identified 22 GLD patients, most had Crohn's disease (CD) (n=17). Drug related GLD was found in $36 \%$ of patients. Ten patients (45.4\%) required hospitalization. Causative drug was stopped in all drug related GLD and $81 \%$ of patients received systemic steroids. Remission of both conditions was achieved in almost all patients. CONCLUSIONS ILD and GLD although rare can cause significant morbidity. In our series over half of cases were drug related and therefore focused pharmacovigilance is needed to identify and manage these cases.
\end{abstract}

DOI: https://doi.org/10.1093/ecco-jcc/jjz165

Posted at the Zurich Open Repository and Archive, University of Zurich ZORA URL: https://doi.org/10.5167/uzh-181139

Journal Article

Originally published at:

Eliadou, Elena; Moleiro, Joana; Ribaldone, Davide Giuseppe; et al; Vavricka, Stephan R (2020). Interstitial and Granulomatous lung disease in inflammatory bowel disease patients. Journal of Crohn's Colitis, 14(4):480-489. DOI: https://doi.org/10.1093/ecco-jcc/jjz165 


\section{Title: Interstitial and Granulomatous lung disease in inflammatory bowel disease patients}

Elena Eliadou ${ }^{1}$, Joana Moleiro ${ }^{2}$, Davide Giuseppe Ribaldone ${ }^{3}$, Marco Astegiano ${ }^{3}$, Katja Rothfuss ${ }^{4}$, Carlos Taxonera ${ }^{5}$, Fahd Ghalim ${ }^{6}$, Franck Carbonnel ${ }^{6}$, Bram Verstockt $^{7}$, Stefano Festa ${ }^{8}$, Luís Maia ${ }^{9}$, Ana Berrozpe ${ }^{10}$, Edyta Zagorowicz ${ }^{11}$, Edoardo Savarino ${ }^{12}$, Pierre Ellul ${ }^{13}$, Stephan R Vavricka ${ }^{14}$, Marta Calvo $^{15}$, Ioannis Koutroubakis ${ }^{16}$, Frank Hoentjen ${ }^{17}$, Luis Fernández Salazar ${ }^{18}$, Francesca Callela $^{19}$, Fiorella Cañete Pizarro ${ }^{20}$, Konstantinos Soufleris ${ }^{21}$, Elena Sonnenberg ${ }^{22}$, Maryan Cavicchi ${ }^{23}$, Joanna Wypych $^{24}$, Christophe Hommel ${ }^{25}$, Alessandro Ghiani ${ }^{26}$, Gionata Fiorino ${ }^{27,28}$ for the ECCO CONFER COMMITTEE $^{29}$

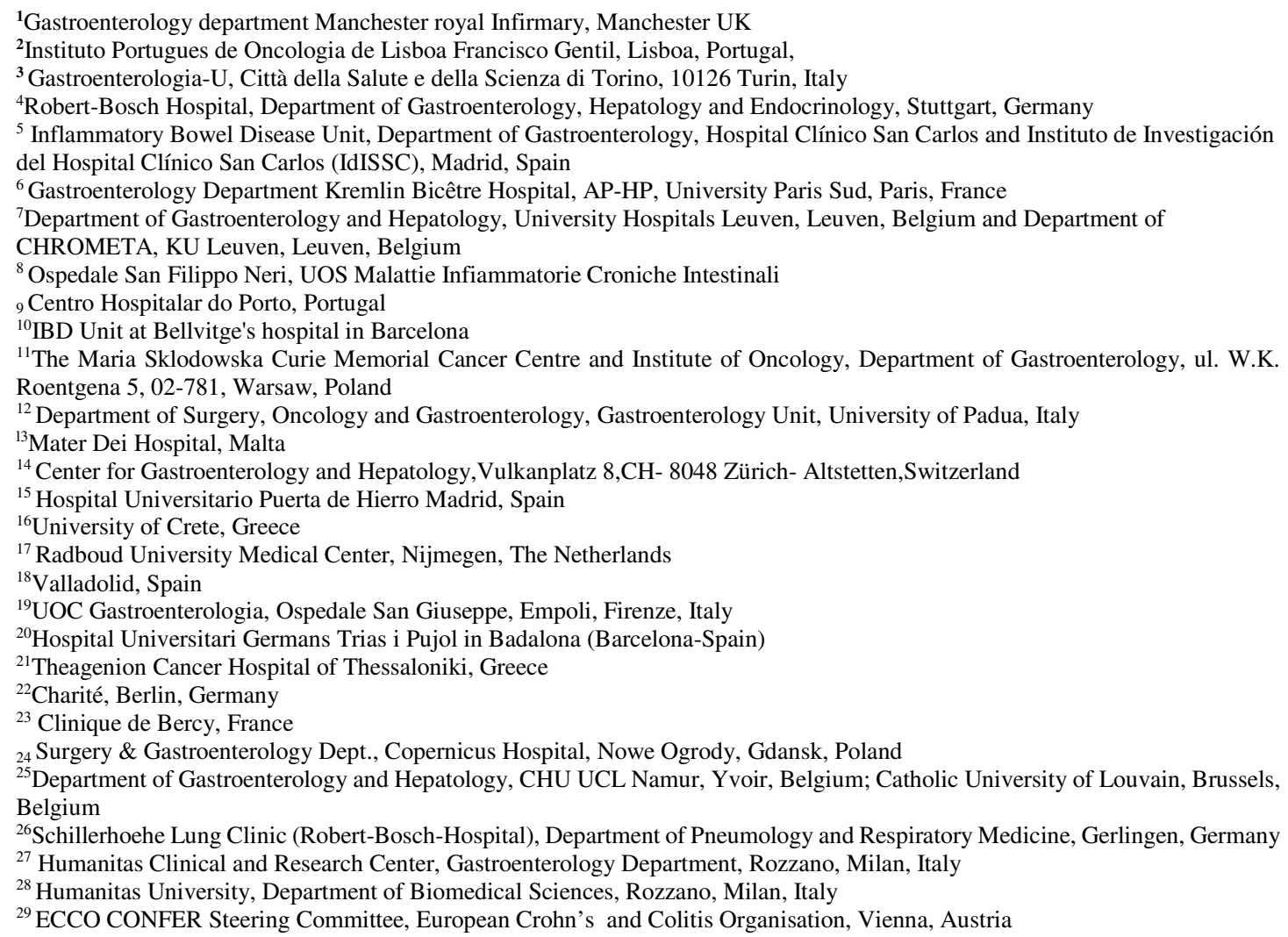




\section{Abstract}

Background: Interstitial lung (ILD) disease and Granulomatous lung disease (GLD) are rare respiratory disorders that have been associated with inflammatory bowel disease (IBD). Clinical presentation is polymorphic and aetiology is unclear.

Methods: This was an ECCO-CONFER project. Cases of concomitant GLD or ILD and IBD or drug induced ILD/GLD were collected. The criteria for diagnosing ILD and GLD were based on definitions from the American Thoracic society and European Respiratory society and on the discretion of reporting clinician.

Results: We identified 31 patients with ILD, most of them with ulcerative colitis (UC) (n=22). Drug related ILD was found in $64 \%$ of patients. Twenty five patients $(80.6 \%)$ required hospitalization and 1 required non-invasive ventilation. Causative drug was stopped in all drug related ILD and $87 \%$ of patients received systemic steroids. At follow up $45 \%$ of patients had no respiratory symptoms, $22.5 \%$ had partial improvement and 13\% had ongoing symptoms. One patient underwent lung transplantation and 1 death from lung fibrosis was reported. We also identified 22 GLD patients with mean age of 46 years (18-86), most of them with Crohn's disease (CD) $(n=17)$. Fourteen patients had non drug related GLD. Ten patients $(45.4 \%)$ required hospitalization but none required invasive ventilation. Causative drug was stopped in all drug related GLD and $81 \%$ of patients received systemic steroids. Remission of both conditions was achieved in almost all patients.

Conclusions: ILD and GLD although rare can cause significant morbidity. In our series over half of cases were drug related and therefore focused pharmacovigilance is needed to identify and manage these cases. 


\section{Introduction}

Up to $50 \%$ of IBD patients experience at least one extra-intestinal manifestation (EIM), such as pyoderma gangrenosum, uveitis, episcleritis, polyarthritis or thromboembolic disease ${ }^{1-3}$. Bronchopulmonary manifestations, despite being considered rare with an unknown prevalence, are increasingly recognized.

The presentation of broncho-pulmonary manifestations in IBD patients is polymorphic, as all segments of the respiratory tract can be affected. Generally, pulmonary involvement in IBD may be associated with IBD medication or an EIM of the disease itself. ${ }^{4}$

IBD related lung disease can be subclassified into airway diseases, autoimmune disorder, interstitial lung disease, granulomatous disease and fistulas (Table 1$)^{5}$. Particularly, interstitial lung disease (ILD) and granulomatous lung disease (GLD) and are both rare respiratory conditions. GLD, mimicking parenchymal sarcoidosis, may be observed in $\mathrm{CD}$ patients. In fact, patients with $\mathrm{CD}$ and concomitant sarcoidosis have been reported in the literature, suggesting a link between the two diseases, which share susceptibility genes ${ }^{4}$. ILD is a heterogeneous group of disorders characterized by varying degrees of fibrosis and inflammation of lung parenchyma. There are estimates of more than 200 known causes of ILD leading to symptoms and radiological changes. These diseases can be classified based on the definitions from the American Thoracic society and European Respiratory society ${ }^{5-7}$.

Drug related lung disease can present with either interstitial lung disease or granulomatous disease. The diagnosis of drug related disease can be based on several criteria ${ }^{8}$ :

1. A history of drug exposure with correct identification of the drugs, its duration and administration

2. Clinical imaging and histopathological patterns which are consistent with earlier observations of the same drug

3. Exclusion of other lung disease

4. Improvement after discontinuation of drug suspected

5. Recurrence of symptoms on rechallenge

In our case series the diagnosis was made at the discretion of different clinicians and once other causative causes such as infection were excluded.

We aimed to describe series of IBD patients with a diagnosis of ILD or GLD and try to elicit the impact of the respiratory disease in IBD and outcome. 


\section{Methods}

\subsection{Study design}

This observational multicentre study retrospectively collected cases across the world through the CONFER (COllaborative Network For Exceptionally Rare case reports) project ${ }^{9}$ and supported by the European Crohn's and Colitis Organisation (ECCO). The CONFER project was initiated by ECCO in order to specifically identify and report rare IBD disease associations, which are otherwise seldom reported due to their exceptional rarity. Briefly, the CONFER methodology comprised selecting a topic worthy of investigation out of case proposals submitted by ECCO members. The steering committee of CONFER chose the topic, and ECCO launched a call to identify similar cases encountered by IBD physicians worldwide.

The call to physicians was made through announcements in the ECCO annual congress and in national IBD meetings across Europe and during several international IBD meetings. In addition, the call for similar cases was disseminated by direct emails to all ECCO members and affiliated physicians, and on the ECCO website and in the ECCO eNews. Physicians were then prompted to report their cases to the CONFER database using a pre-determined standardized case report form. The call for the present case series was entitled Interstitial and granulomatous lung disease in IBD.

\subsection{Patients and procedures}

All adult IBD patients (age > 16 years) with a GLD or ILD diagnosis, according to established classifications $^{6,7}$ throughout the course of IBD or prior to its diagnosis were eligible for inclusion in this study. GLD and ILD diagnosis was made based on clinical presentation according to prior case reports and reviews. Relationship between IBD treatment and pulmonary disease was established by the physician, based on the patients' medical history and relevant tests, when applicable. Data were collected using a case report form, which was divided into five domains. Section 1 included patient (epidemiological data, past medical history, smoking habits, previous lung disease) and disease characteristics. Section 2 was focused on event description, Section 3 on event presentation and investigations, Section 4 on treatment and section 5 on respiratory and IBD outcomes. All the participating centres reviewed patient charts and enrolled all the patients eligible. The data were 
collected and analysed anonymously and handled according to local regulations. All the adverse events discussed in the text and related to any drug have been reported to the Pharmacovigilance according to the local regulations.

\subsection{Statistics}

For the statistical analysis, IBM Software SPSS Statistics Version 22.0.0 (2013 SPSS Science, Inc., Chicago, IL) was used. Depending on the number and the distribution of the data, appropriate tests were used to analyse the data. 


\section{Results}

\subsection{Interstitial lung disease patients}

A total of 31 patients with ILD were identified from 14 medical centres. Patients' characteristics are shown in Table 2. All patients had a diagnosis of IBD prior to ILD with a median time of 10.3 years (range 0.3-51 years). Eight (25.8\%) patients had IBD disease activity at the time of ILD diagnosis. Eleven $(35.5 \%)$ patients had non drug related ILD and $20(64.5 \%)$ had drug related ILD (mesalazine $n=9$, methotrexate $n=1$, golimumab $n=1$, vedolizumab $n=1$ and infliximab (IFX) $n=8$ ). One patient had 2 different drugs induced ILD related to vedolizumab and golimumab and each event was analysed separately. Main characteristics and outcomes of reported ILD are shown in Figure 1.

\subsubsection{Non drug related data}

Eleven patients were identified, $10(90.9 \%)$ male, with mean age at event 51.6 years (range 2067 years). Mean duration of IBD was 13.3 years (range 1.3-51 years) at the time of the event. Eight (72.7\%) patients had previous lung disease (asthma $n=1$, previous Pneumocystis jirovecii (PJ) pneumonia $n=1$, pulmonary embolus $n=1$, previous p ANCA $n=1$, not specified $n=4$ ) (Table 2). The main reported symptoms were cough $(n=10,90.9 \%)$, shortness of breath SOB $(n=9,81.8 \%)$, fever $(n=2$, $18.1 \%)$ and lethargy $(\mathrm{n}=3,27.2 \%)$ with duration of symptoms varying from 12 days to 1 year.

Investigations showed that 8 patients (72.2\%) had abnormal Chest X-ray (CXR), two had positive autoantibodies (1 ANA positive and 1 ANCA positive). All had abnormal chest high resolution computerized tomography (HRCT). Bronchoscopy was done in seven patients $(63.6 \%)$ (abnormal $n=3$, normal $n=4)$. Only 6 patients $(54.5 \%)$ underwent lung biopsy (Table 2). Diagnoses of ILD included Cryptogenic Organizing Pneumonia (COP) in five patients (45.4\%), idiopathic fibrosis in $3(27.3 \%), 3$ (27.3\%) unclassified. Nine patients $(81.8 \%)$ were hospitalized and seven (63.6\%) received steroids and 4 of those for long term. One of the patients required non-invasive ventilation with BIPAP duration on 1 month.

At mean follow up of 10 months (ranging from 4 months to 9 years) 3 (27.3\%) had ongoing symptoms, 5 (45.4\%) had complete resolution of symptoms and 1 had ongoing symptoms despite long term steroids and was then given methotrexate and referred for consideration of lung transplantation, whereas data were missing for 2 patients. On review, 2 (18.2\%) had abnormal CXR, 5 (45.4\%), 3 (27.3\%) had abnormal HRCT. Eight patients (72.7\%) had active IBD, two (18.2\%) quiescent and three 
$(27.3 \%)$ had a flare. Out of those who had a flare one was started on adalimumab, one on IFX and one on tacrolimus. One of the patients underwent proctocolectomy for colonic dysplasia. ILD characteristics and outcome are also summarized in Supplementary Table 1.

\subsubsection{ILD: Drug related data}

A total of twenty cases were identified (mesalazine $n=9$, methotrexate $n=1$, golimumab $n=1$, vedolizumab $n=1$ and IFX n=8). Patients' epidemiological and IBD characteristics are summarized in Supplementary Table 2 and 3.

\subsubsection{Biologics}

\section{Anti TNF}

$\operatorname{Infliximab}(I F X)$

There were 8 cases (40\% of drug related cases) with IFX induced interstitial lung disease. Patients were on IFX $(5 \mathrm{mg} / \mathrm{kg})$ with a mean duration of 5.4 doses (range 2-8 doses). Main symptoms were: cough $(n=6,75 \%)$, SOB $(n=8100 \%)$, fever $(n=3 \quad 37.5 \%)$ and lethargy $(n=450 \%)$ with a mean duration of symptoms of 6.3 weeks (1 day-24 weeks). All patients had negative virology and bacterial screen. Five (62.5\%) had abnormal CXR and six (75\%) all of them had abnormal HRCT and only 1 had abnormal bronchoscopy. Only $3(37.5 \%)$ had lung biopsy done.

Diagnosis included 3 with COP (37.5\%), 2 with idiopathic fibrosis (25\%) and 3 (37.5\%) with unclassified interstitial lung disease. Five patients (62.5\%) were admitted and IFX was stopped in all patients. Once infection was excluded, six patients received steroids (75\%) for duration between 1-6 months.

At mean follow up of 4.6 months (ranging from 1-14 months), 5 (62.5\%) patients had ongoing symptoms. Five (62.5\%) had normal CXR, 1 (12.5\%) still had ongoing abnormalities. CT was normal in 1 patient (12\%), but the majority (6) had ongoing abnormalities (75\%). Three of these patients showed improvement. With regards to IBD, 4 had active disease at follow up (50\%), 3 had quiescent disease (37.5\%). Two required steroids to control their disease and 5 had new medications initiated (5ASA $n=1$, AZA $n=1$. adalimumab $n=1$, vedolizumab $n=1$, ustekinumab $n=1$ ).

\section{Golimumab}

There was only one case of female patient (5\% of drug related cases) with UC E3 undergoing golimumab and vedolizumab. Clinical characteristics are included Supplementary Table 2. There was previous use of IFX and vedolizumab and previous lung disease due to vedolizumab with acute 
interstitial pneumonia. She presented at age 24 after 2 doses of golimumab and active IBD at event. Symptoms included cough, SOB, fever and lethargy. She had abnormal CXR and HRCT. Diagnosed as cryptogenic organizing pneumonia and admitted to hospital and treated with steroids for 1 month. Despite treatment, she had ongoing active IBD that required steroids and was readmitted and had surgery subtotal colectomy and ileostomy.

\section{Vedolizumab}

The same patient (as above) previously developed ILD (Unclassified) disease duration at event was 12 years and age at presentation was 24 years. Lung disease presented with SOB after 2 doses of vedolizumab with: cough, SOB, fever, lethargy. She had abnormal CXR, HRCT, and bronchoscopy. She was diagnosed with and treated with steroids and was admitted to hospital. Had ongoing active IBD at review 4 months later and was admitted with a flare that required steroids and started Golimumab.

\subsubsection{5 ASA}

There were 9 patients (45\% of drug related cases), 6 of them male $(66.7 \%)$. Two (22.2\%) patients had previous lung disease (asthma $n=1$, Sjogren's syndrome $n=1$ ). Patients' ILD characteristics and outcomes are summarized in Supplementary Table 3. Mean age at time of event was 52 years (ranging from 19-80 years) with mean duration of IBD 6.6 years ( ranging from 0.8-14 years). At the time of event two (22.2\%) patients had active disease, and seven $(77.8 \%)$ had quiescent.

5-ASA means dose at event was $2.3 \mathrm{~g}$ (range 0.8-3 g) and means duration of 5-ASA use was 5.11 years (range 0.8-14 years). Presenting symptoms were: cough $(n=7)$, SOB $(n=8)$, fever $(n=6)$, lethargy $(n=1)$ with mean duration of 7.5 weeks (ranging from 1.5-12 weeks). All patients had abnormal CXR and CT. One had abnormal bronchoscopy (11.1\%) and only two had lung biopsy (22.2\%). Diagnosis included 2 patients with COP (22.2\%) 5 had ILD unclassified (55.5\%), 1 with idiopathic interstitial disease $(3.3 \%)$ and 1 with eosinophilic pneumonia (3.3\%). The drug was stopped in all patients. Eight $(88.9 \%)$ patients were admitted to hospital, and treated with steroids $(88.9 \%)$ with mean duration of 6.47 months (0.3-24 months). 2 with long term use. Any infection was excluded prior to commencing steroids.

At mean follow up of 11.6 months, (ranging from 3-24), 5 patients (55.5\%) had ongoing symptoms, 4 had abnormal CXR (44.4\%), 2 (50\%) had improvement. Three (33.3\%) had abnormal HRCT. One (11\%) became steroid dependent and died 5 years later due to progressive lung disease. After treatment, 1 patient (11\%) had a flare that required steroids, $3(33.3 \%)$ started new medications 
(AZA, steroids 1 restarted 5-ASA). 5-ASA induced ILD characteristics and outcome are also summarized in Supplementary Table 3.

\subsubsection{Methotrexate}

Only 1 patient (5\%) was identified, a female with CD L2. Age at event was 44 years old and at presentation was on MTX for 2 years with $15 \mathrm{mg}$ every week and her IBD was in remission. Presented with cough, SOB, fever and lethargy that lasted few days. Abnormal CXR and spirometry (mixed restrictive and obstructive pattern) and also abnormal HRCT were reported. She was treated with steroids for 1 month after being admitted to hospital. A diagnosis of ILD (Unclassified) was made. At review 1 month later she had lethargy, normal CXR. Subsequently, she had a flare of her CD and adalimumab was started 3 years later.

\subsection{Granulomatous lung disease patients}

We identified 22 GLD patients from 18 university hospitals, most of them with CD (77.3\%). Patients' characteristics are shown in Table 2. In 17 patients, IBD diagnosis preceded lung disease diagnosis in a median time of 10.6 years (range $0.5-27$ years); only 4 patients had active disease at the time of GLD diagnosis. In 4 patients, lung disease was diagnosed in a median time of 14 months (range 8-24 months) before IBD and in 1 patient IBD and lung disease diagnoses were established simultaneously.

A total of 14 cases $(63.6 \%)$ were considered non drug related GL (primary sarcoidosis n=7, fungal infection $n=2$ and unspecified $n=5)$ and 8 cases (36.4\%) were considered drug-related GLD (IFX $n=4$, certolizumab $n=1$, adalimumab $n=1$, vedolizumab $n=1$ and azathioprine (AZA) $n=1$ ) out of which 5 had sarcoidosis. Characteristics of GLD and outcomes are shown in Figure 2.

\subsubsection{Non drug related GLD}

We identified 14 patients (63.6\%) with non-drug related GLD and IBD, 11 male (78.6\%), with mean age at event of 44.5 years (range $18-85$ years). At event only 4 patients had active IBD disease. Nine patients presented with cough (64.3\%), 4 with SOB (28.6\%), 2 with fever (14.3\%) and 2 with weight loss (14.3\%). Investigations showed that 12 patients had abnormal CT scan (85.7\%), $11(78.6 \%)$ had abnormal CXR, 4 had abnormal spirometry (28.6\%, restrictive pattern $n=2$, obstructive pattern $n=2)$. Three had abnormal bronchoscopy and 12 patients $(85.7 \%)$ had a lung biopsy compatible with granulomatous non-necrotizing disease. 
Diagnosis was primary sarcoidosis in seven patients (50\%) (6 males; 4 patients with CD and 3 with UC). 1 patient was under anti-TNF therapy (adalimumab), 1 was under immunosuppressive therapy (AZA), 2 under 5-ASA therapy and 3 without therapy. The first patient was under adalimumab therapy for just only 1 month when the diagnosis of sarcoidosis was established. Due to progressive deterioration with weight loss, fatigue and arthralgia, further investigation was made which revealed systemic granulomatosis with skin, lung, spleen, bone, heart, bone marrow, joint (right knee) and gastro-intestinal involvement. Due to severe lung deterioration and cardiac involvement, a high dose of steroids was initiated.

In the remaining 6 patients both diagnosis of $\operatorname{IBD}(\mathrm{CD} n=3, \mathrm{UC}=3)$ and sarcoidosis were made: initially all patients received steroids and during the follow up 2 patients started on immunosuppression with AZA achieving remission of both conditions, whereas 1 UC patient, who had already been submitted to proctocolectomy, was started on immunosuppression with MTX due to ongoing respiratory symptoms.

Five patients $(36 \%)$ were considered to have an unspecified GLD ( 3 males; all of them with CD): 2 patients had no IBD medication (lung disease was established before or at the same time as IBD), 2 patients were under 5-ASA and 1 under MTX. All patients initially received steroids. Additionally, during the follow up, 4 patients started anti-TNF therapy (adalimumab), of whom 3 achieved steroidfree remission of both conditions.

We identified 2 patients (14\%) (2 males; 1 patient with CD and 1 with UC) with a GLD caused by a fungal infection: 1 patient was under systemic steroid therapy and 1 patient had the diagnosis of pulmonary histoplasmosis made before IBD diagnosis. At follow up, both patients had no ongoing pulmonary symptoms. With regards to IBD, the first patient had pancolitis and during the follow up was submitted to surgery (IPAA) to control IBD and the other still had disease activity despite the introduction of budesonide therapy.

Among patients with non-drug related GLD hospital admission was needed in 8 patients $(57.1 \%)$ but none needed invasive ventilation. Remission of both conditions was achieved in almost all patients.

\subsubsection{Drug related GLD}

We identified 8 patients $(36.4 \%$ ) with drug related GLD (IFX $n=4$, certolizumab $n=1$, adalimumab $n=1$, vedolizumab $n=1$ and AZA $n=1)$ and IBD, 6 males $(75.0 \%)$, with mean age at event 
48.1 years (35-76 years). At event presentation only 1 patient had active IBD disease. Six patients presented with cough (75.0\%), 5 with SOB 62.5\%), 5 with lethargy $(62.5 \%), 3$ with fever $(37.5 \%)$ and 2 with weight loss $(25.0 \%)$. Investigations showed that all patients had abnormal thorax CT scan and 3 had abnormal spirometry $(37.5 \%$, restrictive pattern $n=2$, mixed pattern $n=1)$. Bronchoscopy was done in 7 patients (abnormal $n=2$, normal $n=5$ ). Most of patients $(n=5,62.5 \%)$ had lung biopsy, all of them compatible with granulomatous non-necrotizing disease

\subsubsection{Biologics}

\section{Anti-TNF}

There was a total of 6 cases $(75.0 \%$ of drug related cases) with anti-TNF induced GLD. Diagnosis included 5 patients with sarcoidosis (83.3\%) and one with GLD unspecified (16.7\%). In the sarcoidosis group $(n=5)$ (3 males, 4 with CD), mean age of 41.4 years: all of them were under anti-TNF therapy (IFX n=3, adalimumab $n=1$, certolizumab $n=1$ ) for a mean time of 55 months (range 10-108). Causative drug was stopped in all patients and 2 also received steroids. At mean follow up of 33 months (range 12-84 months) there were no patients with ongoing respiratory or IBD symptoms. 3 patients were started on vedolizumab therapy and 1 patient treated with IFX was successfully switched to adalimumab (data not available for 1 patient). In 1 male patient with CD who was on IFX for 72 months he had diagnosis of GLD (non-sarcoidosis) related to anti-TNF. The anti-TNF was stopped and was given steroids with resolution of respiratory symptoms. When reviewed at 3 months and AZA was started for maintenance of his IBD. The patient also received steroids with resolution of respiratory symptoms.

\section{Vedolizumab}

There was only one case of a male patient with CD (12.5\% of drug related cases). This patient had the diagnosis of CD established 7 years before and had already been treated with AZA and golimumab. After 4 months of vedolizumab therapy (300mg q4w) he developed cough, SOB and lethargy. He had a diagnosis of GLD secondary to vedolizumab. Vedolizumab was stopped and he was treated with steroids with resolution of respiratory symptoms. Due to active IBD, 15 months later he was started on anti-TNF therapy.

\subsubsection{Azathioprine (AZA):}

There was only one case of male patient with $\mathrm{CD}$ (12.5\% of drug related cases). This patient had the diagnosis of CD established 7 years before and was in remission under AZA $(2.5 \mathrm{mg} / \mathrm{Kg})$. After 24 months of AZA he developed cough, SOB and lethargy and it was established the diagnosis of 
unspecified GLD. The patient was admitted, AZA was stopped and he was treated with steroids. Four years later the patient still needed steroids $(10 \mathrm{mg} /$ day) to control respiratory symptoms and still had abnormal CT chest and spirometry. There was no need for new IBD therapy.

Among patients with drug related GLD hospital admission was needed in 2 patients (25\%) but none needed invasive ventilation. Remission of both conditions was achieved in all patients, with only 1 patient still needed steroid to control lung disease 


\section{Discussion}

Even though pulmonary manifestations in IBD are rare they are increasingly recognised ${ }^{10,11}$. The true prevalence in IBD remains unknown ${ }^{12,13}$. Our retrospective study describes a series of IBD patients affected by ILD $(n=31)$ and GL $(n=22)$. Most of cases were reported to be drug related $(n=28)$ and 25 were non drug related cases. Most of the current data in literature comes from rheumatological patients and also small case series and our study provides insight into the IBD population.

Establishing an accurate diagnosis of ILD can be challenging for clinicians as there are more than 200 different subtypes and over the past decade ILD has been reclassified in comprehensive international consensus statements ${ }^{6,7}$. Determination of disease subtypes requires consideration of patients' clinical features, radiological pattern, and serology and in some cases lung biopsy. ${ }^{14}{ }^{15-21}$.

Granulomatous lung disease diagnosis can also be challenging to diagnose. Even with histology it can be difficult to distinguish between sarcoidosis and Crohn's disease. In fact, both entities are barrier disorders of unknown aetiology, with several aspects in common (non-necrotizing granulomas, an increased intestinal permeability, local and peripheral T-cell activation and an increased proinflammatory cytokine release $)^{22-27}$. Moreover, the patterns of possible organ involvement outside the primary manifestations in the lung and gut are similar and include eye, skin, joints and liver. Sarcoidosis manifestations in the gut, $\mathrm{CD}$ manifestations in the lung and manifestations of both diseases in the same patient have been reported in rare cases, which may impose considerable diagnostic difficulties ${ }^{22-27}$.

In our case series, 11 patients had non drug induced ILD with male predominance and $73 \%$ with pre-existing lung disease and concomitant UC. None of the pre-existing lung disease included previous ILD. Only 6 patients had lung biopsy making classification difficult with 3 cases unclassified. Three cases were diagnosed as IPF which is a progressive lung disease two of which had ongoing respiratory symptoms and radiological changes but one no respiratory data exist. One of the ILD unclassified cases had progressive deterioration of his respiratory symptoms requiring referral for consideration of lung transplantation despite ongoing steroid treatment. A high proportion of were admitted and treated with steroids with resolution of symptoms in $45 \%$ of patients, which possibly is related to the ILD subtype of COP, which has a good prognosis and responds to steroid treatment.

We also identified 14 patients with non-drug related GLD and 12 patients had lung biopsy. Diagnosis was 7 patients with sarcoidosis and 5 had GLD unclassified which again demonstrates the 
difficulty in diagnosis, 2 cases were due to fungal infection. Almost all cases recovered with the use of steroids and AZA (sarcoidosis) or IFX (unspecified GLD).

The most common pulmonary manifestations of IBD are drug-induced lung disease. Most of IBD drugs have been implicated and definitive diagnosis of drug induced lung disease can be difficult. Clinical presentation and exclusion of other causes play important role in making the diagnosis, but sometimes invasive procedures such as bronchoscopy and lung biopsy might be necessary ${ }^{22-27}$. Patients can present with virtually all histopathological patterns of either ILD or GLD. Moreover some drugs can produce more than one pattern of respiratory involvement. There have been some risk factors for developing drug related lung disease include: extremes of age, sex, ethnicity, dose of medication, oxygen, drug interaction and underlying lung disease ${ }^{28}$. Diagnostic criteria exist as mentioned earlier but despite that it can still be a difficult diagnosis ${ }^{8}$.

Sulfasalazine and mesalazine, side effects are rare and can be dose related or idiosyncratic. Mesalazine induced lung injury is rare and usually presents as interstitial and eosinophilic pneumonitis, bronchiolitis obliterans and eosinophilic pleural effusion ${ }^{29}$. Case report data suggest mesalazine induced lung toxicity follows a milder course, however, there have been case reports with more severe presentation requiring intubation ${ }^{30}$. A recent review of 50 cases of sulphasalazine lung toxicity most patients presented with cough, breathlessness, fever and weight loss. Most of cases presented with chronic interstitial pneumonias, desquamative interstitial pneumonitis, eosinophilic pneumonitis and acute interstitial pneumonia. Clinical improvement occurred in majority of cases with resolution occurring with average for $61 / 2$ weeks after initiation of therapy. There were 5 deaths due to pulmonary pathology and all cases had UC as underlying condition ${ }^{31}$. In another review of case reports of 5-ASA induced lung toxicity, mean age of presentation was 46 years with most cases being female and having UC as underlying disease. The time for appearance of symptoms ranged from 2 days to 8 years ${ }^{32}$. 5-ASA lung toxicity usually responds to discontinuation of drug and some may require a course of steroids ${ }^{33}$. In our case series we identified 9 cases and unlike the literature most of them were male (67\%) and $89 \%$ had ulcerative colitis. The mean duration use of 5ASA was 5.1 years (range 0.8-14 years) which is similar to the previous review. Only 2 patients had lung biopsy and most cases were ILD unclassified. At follow up 55\% of them had ongoing respiratory symptoms. There was 1 death due to progressive fibrosis. This 
was an 81 year-old male patient that was diagnosed with idiopathic pulmonary fibrosis and became steroid dependent.

The use of anti-TNF drugs (IFX, adalimumab, golimumab, certolizumab) in IBD has increased and improved the outcomes of IBD patients ${ }^{34,35}$. The most important side effects include increased risk of opportunistic infections ${ }^{36}$. There has been some evidence that anti-TNF therapy can cause acute respiratory distress syndrome, diffuse alveolar haemorrhage ${ }^{37}$ and $\operatorname{ILD}^{38-41}$. A large scale post-marketing surveillance study in Japan on safety of IFX in rheumatology patients revealed that the development of ILD was a rare event of $0.5 \%$ (25/5000). Mean age of those patients was 62.9 years and pneumonitis occurred after a mean dose of 2.8 infusions of $\mathrm{IFX}^{42}$. Another case control study from Nakashita investigated the potential risk of TNF inhibitors on progression of ILD in patients with RA revealed increased risk of ILD events and also progression of pre-existing ILD disease ${ }^{43}$. Patients presented mostly with dyspnoea and cough with IFX use of 6-14 weeks prior to presentation. Diagnosis included: nonspecific interstitial pneumonitis, drug related alveolitis, drug induced interstitial lymphocytic pneumonitis; all had discontinuation of IFX with complete resolution of symptoms with steroids ${ }^{44-46}$. There has been one case report of fatal acute interstitial pneumonia after accelerated dose of IFX for acute severe $\mathrm{UC}^{47}$. In our case series we identified 8 IFX induced ILD cases with male predominance. Only 2 patients had lung biopsy. One young male was diagnosed with idiopathic pulmonary fibrosis but he responded to steroids and therefore unclear whether that diagnosis was the correct one. Most of our patients had ongoing symptoms and radiological changes despite steroid treatment and discontinuation of the drug. The different outcome might be due to the diversity of the subtype of ILD as different subtypes have different outcomes.

Another uncommon pulmonary adverse event associated with anti-TNF therapy is the development of sarcoid like lesions. The estimated frequency is 1:28000 (0.04\%) which comes from case reports published from rheumatological data ${ }^{48,49,50}$. Symptoms are nonspecific, including dyspnoea, non-productive cough, erythema nodosum, parotid enlargement, and neuro-ocular manifestations. Radiologically, the most common findings are mediastinal and hilar adenopathy, and less frequently, upper lobe opacities. The diagnosis is confirmed histologically by the presence of well-formed nonnecrotizing granulomas. Ultimately, sarcoidosis is a diagnosis of exclusion, once all infectious causes have been ruled out ${ }^{51}$. In a recent review of the available literature, the authors evaluated the published 
cases of sarcoidosis associated with anti-TNF therapy and found a total of 90 patients with median age of 43 years (7-72) and a female predominance $(61 \%)$. The underlying anti-TNF therapy was etanercept $(n=53,59 \%)$, adalimumab $(n=21,23 \%)$ and $\operatorname{IFX}(n=16,18 \%)$ and the median duration between initiation of anti-TNF therapy and diagnosis was 22.5 months (1-84). Regarding treatment options, in 43 cases, the anti-TNF therapy was discontinued and steroids were started, with an improvement or resolution in 41 cases $(95 \%)$, in 37 cases, anti-TNF discontinuation was the only intervention, giving improvement in 32 cases $(86 \%)$, in 5 cases, addition of steroid therapy alone gave improvement in 4 cases (80\%), in 1 out of 3 cases improvement was observed without any intervention (33\%). In 20 cases, the anti-TNF was restarted therapy: in 6 cases the same drug was used, which gave recurrence in 4, and in 14 cases, another anti-TNF was initiated with relapse in $3^{52}$. In our series we found a male predominance but the other characteristics and outcomes are similar to those previously reported. All patients fully recovered by stopping anti-TNF therapy and receiving steroids.

No data exists on IBD population regarding golimumab induced ILD. According to the EMA 2009 Assessment report, serious non-infectious pulmonary adverse events were observed in five Phase 3 trials of golimumab for the treatment of rheumatoid arthritis, ankylosing spondylitis or psoriatic arthritis: 1 case of interstitial disease, 2 of pneumonitis and 1 of fibrosing alveolitis ${ }^{53-58}$. Most of patients were also on methotrexate and therefore unable to make a definite association between ILD and golimumab. We reported a case of a young woman with previous use of IFX and previous lung disease due to vedolizumab who had golimumab induced COP and required steroids. Unfortunately, no respiratory follow up data was available but ended up having subtotal colectomy and ileostomy for UC after 2 months following further flare after stopping golimumab.

Vedolizumab, unlike other drugs used for IBD, has not been associated with the development of serious opportunistic infections and malignancies ${ }^{59}$. However, clinical observations indicate an increased risk for extra-intestinal autoimmune events under this therapy ${ }^{60}$. There have been 2 case reports of ILD in the literature ${ }^{61,62}$. The only case of vedolizumab related ILD (Unclassified subtype) reported in our cohort responded to steroids but had further admissions due to flare of her disease and required golimumab therapy.

We also reported a case of a CD male patient who developed cough, shortness of breath and lethargy 4 months after starting vedolizumab. He was diagnosed as GLD associated with vedolizumab 
therapy, but, as the similar case recently published ${ }^{63}$, this patient can be re-classified as a patient with newly developed pulmonary manifestation of $\mathrm{CD}$ under vedolizumab.

MTX may be useful in IBD treatment but can cause adverse events in lungs that can be lethal ${ }^{64}$. The mechanism is unclear and thought to be an idiosyncratic reaction that can cause interstitial pneumonitis and bronchiolitis ${ }^{65}$. MTX pneumonitis is a rare complication with only 123 case reports in the literature. Most of cases have a subacute onset and it is most common within the first year of treatment, with a reported incidence that varies from 0.8 to $6.9 \%{ }^{66,67}$. Treatment of MTX pneumonitis includes withdrawal of MTX, high dose corticosteroids and supportive therapy ${ }^{67}$. We identified 1 case that presented with ILD unclassified after 2 years of weekly MTX use due to CD who was treated with 1 month of steroids with resolution of symptoms.

Pulmonary toxicity due to AZA/6-MP has been reported infrequently in the literature, although interstitial pneumonitis, restrictive lung disease, Goodpasture-like syndrome and pulmonary haemorrhage have been described after use of these drugs ${ }^{12}$. The largest series of lung toxicity related to AZA with description of 7 cases on AZA therapy was reported in patients undergoing renal allograft transplantation immunosuppression. Lung biopsies revealed interstitial pneumonitis in 5 patients and diffuse alveolar damage in 2 patients; 3 patients died and the other 4 improved after stopping AZA and in 2 of these patients cyclophosphamide therapy to resolve completely this side effect was needed ${ }^{69}$. There are no cases of GLD due to AZA / 6-MP in the literature. Here we described a case of a CD male patient in remission who developed cough, shortness of breath and lethargy 24 months after AZA initiation. He was diagnosed with AZA related GLD and was admitted and responded to steroids and became steroid depended to control his respiratory symptoms, with ongoing radiological and spirometry changes 4 years later.

Our study has several limitations: it was a retrospective case report data collection and it relied on voluntary submission of cases by physicians who responded to the ECCO calls and therefore might be subject to geographical and selection biases. Only 12 ILD cases $(38.7 \%)$ had lung biopsy and 17 GLD cases $(77 \%)$ which resulted in a lot of cases having ILD Unclassified. The classification of ILD and whether a drug was the caveat was depended on the clinician submitting the relevant info and as cases were collected from 2000-2017 the classification might have not been the correct one as classification of ILD has been revised 2013-2015. 
Due to the low sample size the correlation between IBD therapies and lung disease is challenging to assess. Also no risk factors or predictors can be investigated due to the very low sample size, and the heterogeneity of cases.

\section{Conclusion}

ILD and GLD although rare can cause significant morbidity. About half of our cases were drug related and therefore clinicians should be more vigilant regarding IBD medications especially when infectious causes have been excluded. Early recognition and treatment is important as most respond to withdrawal of medication and use of steroids.

\section{Potential conflict of interest}

None declared........ (await declaration from authors)

\section{Specific author contributions}

EE and JM initiated the study: EE analysed and interpreted ILD data and drafted the manuscript ,JM was responsible for analysis and interpretation of data and drafting GLD part of manuscript; GF participated in study design and critically revised the manuscript; all the Authors contributed the cases and were responsible for revision of the manuscript as well as for the treatment of the patients; EE and JM drafted the manuscript, EE revised the manuscript and made the revision. All other collaborating authors on the page contributed with at least one case and critically revised the manuscript. 


\section{References}

1. Bernstein CN, Wajda A, Blanchard JF. The clustering of other chronic inflammatory diseases in inflammatory bowel disease: A population-based study. Gastroenterology 2005;129:827-36.

2. Storch I, Sachar D, Katz S. Pulmonary manifestations of inflammatory bowel disease. Inflamm Bowel Dis 2003;9:104-15.

3. Rothfuss KS, Stange EF, Herrlinger KR. Extraintestinal manifestations and complications in inflammatory bowel diseases. World J Gastroenterol 2006;12:4819-31.

4. Kraft SC, Earle RH, Roesler M, Esterly JR. Unexplained bronchopulmonary disease with inflammatory bowel disease. Arch Intern Med 1976;136:454-9.

5. Black H, Mendoza M, Murin S. Thoracic manifestations of inflammatory bowel disease. Chest 2007;131:524-32.

6. Sverzellati N, Lynch DA, Hansell DM, et al. American thoracic society-european respiratory society classification of the idiopathic interstitial pneumonias: Advances in knowledge since 2002. Radiographics 2015;35:1849-71.

7. Travis WD, Costabel U, Hansell DM, et al. An official american thoracic society/european respiratory society statement: Update of the international multidisciplinary classification of the idiopathic interstitial pneumonias. $\mathrm{Am} \mathrm{J}$ Respir Crit Care Med 2013;188:733-48.

8. Bradley B, Branley HM, Egan JJ, et al. Interstitial lung disease guideline: The british thoracic society in collaboration with the thoracic society of australia and new zealand and the irish thoracic society. Thorax 2008;63 Suppl 5:v1-58.

9. Katsanos KH, Domenech E, Rahier JF, et al. Making a case for case reports: The ecco-confer viewpoint on investigating rare events in a medical world reigned by group-comparative statistics. J Crohns Colitis 2017;11:256-7.

10. Hoffmann RM, Kruis W. Rare extraintestinal manifestations of inflammatory bowel disease. Inflamm Bowel Dis 2004;10:140-7.

11. Loftus EV, Jr. Clinical epidemiology of inflammatory bowel disease: Incidence, prevalence, and environmental influences. Gastroenterology 2004;126:1504-17.

12. Casella G, Villanacci V, Di Bella C, et al. Pulmonary diseases associated with inflammatory bowel diseases. J Crohns Colitis 2010;4:384-9.

13. Lu DG, Ji XQ, Liu X, Li HJ, Zhang CQ. Pulmonary manifestations of crohn's disease. World J Gastroenterol 2014;20:133-41.

14. Disayabutr S, Calfee CS, Collard HR, Wolters PJ. Interstitial lung diseases in the hospitalized patient. BMC Med 2015;13:245.

15. Schlesinger C, Koss MN. The organizing pneumonias: An update and review. Curr Opin Pulm Med 2005;11:422-30.

16. Cordier JF. Cryptogenic organising pneumonia. Eur Respir J 2006;28:422-46.

17. Polverosi R, Maffesanti M, Dalpiaz G. Organizing pneumonia: Typical and atypical hrct patterns. Radiol Med 2006;111:202-12.

18. Yoo JW, Song JW, Jang SJ, et al. Comparison between cryptogenic organizing pneumonia and connective tissue disease-related organizing pneumonia. Rheumatology (Oxford) 2011;50:932-8.

19. Drakopanagiotakis F, Paschalaki K, Abu-Hijleh M, et al. Cryptogenic and secondary organizing pneumonia: Clinical presentation, radiographic findings, treatment response, and prognosis. Chest 2011;139:893-900. 
20. Cohen AJ, King TE, Jr., Downey GP. Rapidly progressive bronchiolitis obliterans with organizing pneumonia. Am J Respir Crit Care Med 1994;149:1670-5.

21. Johkoh T, Muller NL, Taniguchi H, et al. Acute interstitial pneumonia: Thin-section ct findings in 36 patients. Radiology 1999;211:859-63.

22. Freeman HJ, Davis JE, Prest ME, Lawson EJ. Granulomatous bronchiolitis with necrobiotic pulmonary nodules in crohn's disease. Can J Gastroenterol 2004;18:687-90.

23. Shulimzon T, Rozenman J, Perelman M, Bardan E, Ben-Dov I. Necrotizing granulomata in the lung preceding colonic involvement in 2 patients with crohn's disease. Respiration 2007;74:698-702.

24. Ikehara N, Fujimoto K, Sadohara J, et al. Interstitial pneumonia associated with ulcerative colitis: High-resolution computed tomography and pathologic findings. J Thorac Imaging 2013;28:W21-3.

25. Marten K, Fend F, Hautmann H, et al. Case report: Fatal acute exacerbation of usual interstitial pneumonia in ulcerative colitis. $\mathrm{Br} J$ Radiol 2005;78:762-6.

26. Camus P, Piard F, Ashcroft T, Gal AA, Colby TV. The lung in inflammatory bowel disease. Medicine (Baltimore) 1993;72:151-83.

27. Teague WG, Sutphen JL, Fechner RE. Desquamative interstitial pneumonitis complicating inflammatory bowel disease of childhood. J Pediatr Gastroenterol Nutr 1985;4:663-7.

28. Schwaiblmair M, Behr W, Haeckel T, et al. Drug induced interstitial lung disease. Open Respir Med J 2012;6:63-74.

29. Cilloniz R, Chesrown SE, Gonzalez-Peralta RP. Asymptomatic presentation of mesalamine-induced lung injury in an adolescent with crohn disease. BMJ Case Rep 2009;2009.

30. Abraham A, Karakurum A. Acute respiratory failure secondary to mesalamineinduced interstitial pneumonitis. BMJ Case Rep 2013;2013.

31. Parry SD, Barbatzas C, Peel ET, Barton JR. Sulphasalazine and lung toxicity. Eur RespirJ 2002;19:756-64.

32. Sossai P, Cappellato MG, Stefani S. Can a drug-induced pulmonary hypersensitivity reaction be dose-dependent? A case with mesalamine. Mt Sinai J Med 2001;68:389-95.

33. Foster RA, Zander DS, Mergo PJ, Valentine JF. Mesalamine-related lung disease: Clinical, radiographic, and pathologic manifestations. Inflamm Bowel Dis 2003;9:308-15.

34. Cheifetz AS. Management of active crohn disease. JAMA 2013;309:2150-8.

35. Ghosh S. Anti-tnf therapy in crohn's disease. Novartis Found Symp 2004;263:193205; discussion -18.

36. Colombel JF, Loftus EV, Jr., Tremaine WJ, et al. The safety profile of infliximab in patients with crohn's disease: The mayo clinic experience in 500 patients. Gastroenterology 2004;126:19-31.

37. Panagi S, Palka W, Korelitz BI, Taskin M, Lessnau KD. Diffuse alveolar hemorrhage after infliximab treatment of crohn's disease. Inflamm Bowel Dis 2004;10:274-7.

38. Ostor AJ, Chilvers ER, Somerville MF, et al. Pulmonary complications of infliximab therapy in patients with rheumatoid arthritis. J Rheumatol 2006;33:622-8.

39. Ramos-Casals M, Brito-Zeron P, Munoz S, et al. Autoimmune diseases induced by tnf-targeted therapies: Analysis of 233 cases. Medicine (Baltimore) 2007;86:24251.

40. Villeneuve E, St-Pierre A, Haraoui B. Interstitial pneumonitis associated with infliximab therapy. J Rheumatol 2006;33:1189-93.

41. Weatherhead M, Masson S, Bourke SJ, Gunn MC, Burns GP. Interstitial pneumonitis after infliximab therapy for crohn's disease. Inflamm Bowel Dis 2006;12:427-8. 
42. Takeuchi T, Tatsuki Y, Nogami Y, et al. Postmarketing surveillance of the safety profile of infliximab in 5000 japanese patients with rheumatoid arthritis. Ann Rheum Dis 2008;67:189-94.

43. Nakashita T, Ando K, Kaneko N, Takahashi K, Motojima S. Potential risk of tnf inhibitors on the progression of interstitial lung disease in patients with rheumatoid arthritis. BMJ Open 2014;4:e005615.

44. Sen S, Peltz C, Jordan K, Boes TJ. Infliximab-induced nonspecific interstitial pneumonia. Am J Med Sci 2012;344:75-8.

45. Veerappan SG, O'Morain CA. Infliximab-associated alveolitis after treatment for severe left-sided ulcerative colitis. Eur J Gastroenterol Hepatol 2009;21:830-2.

46. Wiener CM, Muse VV, Mark EJ. Case records of the massachusetts general hospital. Case 33-2008. A 63-year-old woman with dyspnea on exertion. $N$ Engl J Med 2008;359:1823-32.

47. Rofaiel R, Kohli S, Mura M, Hosseini-Moghaddam SM. A 53-year-old man with dyspnoea, respiratory failure, consistent with infliximab-induced acute interstitial pneumonitis after an accelerated induction dosing schedule. BMJ Case Rep 2017;2017.

48. Daien CI, Monnier A, Claudepierre P, et al. Sarcoid-like granulomatosis in patients treated with tumor necrosis factor blockers: 10 cases. Rheumatology (Oxford) 2009;48:883-6.

49. Dhaille F, Viseux V, Caudron A, et al. Cutaneous sarcoidosis occurring during antitnf-alpha treatment: Report of two cases. Dermatology 2010;220:234-7.

50. Massara A, Cavazzini L, La Corte R, Trotta F. Sarcoidosis appearing during antitumor necrosis factor alpha therapy: A new "class effect" paradoxical phenomenon. Two case reports and literature review. Semin Arthritis Rheum 2010;39:313-9.

51. Wollina U, Hansel G, Koch A, et al. Tumor necrosis factor-alpha inhibitor-induced psoriasis or psoriasiform exanthemata: First 120 cases from the literature including a series of six new patients. Am J Clin Dermatol 2008;9:1-14.

52. Decock A, Van Assche G, Vermeire S, Wuyts W, Ferrante M. Sarcoidosis-like lesions: Another paradoxical reaction to anti-tnf therapy? J Crohns Colitis 2017;11:378-83.

53. Emery P, Fleischmann RM, Moreland LW, et al. Golimumab, a human anti-tumor necrosis factor alpha monoclonal antibody, injected subcutaneously every four weeks in methotrexate-naive patients with active rheumatoid arthritis: Twentyfour-week results of a phase iii, multicenter, randomized, double-blind, placebocontrolled study of golimumab before methotrexate as first-line therapy for earlyonset rheumatoid arthritis. Arthritis Rheum 2009;60:2272-83.

54. Hadjinicolaou AV, Nisar MK, Bhagat $\mathrm{S}$, et al. Non-infectious pulmonary complications of newer biological agents for rheumatic diseases--a systematic literature review. Rheumatology (Oxford) 2011;50:2297-305.

55. Inman RD, Davis JC, Jr., Heijde D, et al. Efficacy and safety of golimumab in patients with ankylosing spondylitis: Results of a randomized, double-blind, placebocontrolled, phase iii trial. Arthritis Rheum 2008;58:3402-12.

56. Kavanaugh A, McInnes I, Mease P, et al. Golimumab, a new human tumor necrosis factor alpha antibody, administered every four weeks as a subcutaneous injection in psoriatic arthritis: Twenty-four-week efficacy and safety results of a randomized, placebo-controlled study. Arthritis Rheum 2009;60:976-86.

57. Keystone EC, Genovese MC, Klareskog L, et al. Golimumab, a human antibody to tumour necrosis factor \{alpha\} given by monthly subcutaneous injections, in active rheumatoid arthritis despite methotrexate therapy: The go-forward study. Ann Rheum Dis 2009;68:789-96.

58. Smolen JS, Kay J, Doyle MK, et al. Golimumab in patients with active rheumatoid arthritis after treatment with tumour necrosis factor alpha inhibitors (go-after 
study): A multicentre, randomised, double-blind, placebo-controlled, phase iii trial. Lancet 2009;374:210-21.

59. Colombel JF, Sands BE, Rutgeerts P, et al. The safety of vedolizumab for ulcerative colitis and crohn's disease. Gut 2017;66:839-51.

60. Baumgart DC, Bokemeyer B, Drabik A, Stallmach A, Schreiber S. Vedolizumab induction therapy for inflammatory bowel disease in clinical practice--a nationwide consecutive german cohort study. Aliment Pharmacol Ther 2016;43:1090-102.

61. Nambiar S, Karippot A, Oliver T. Vedolizumab-associated acute respiratory distress syndrome. American Journal of Therapeutics 2018;25:e592-e3.

62. Collins HW, Frye JW. Interstitial lung disease in a 70-year-old man with ulcerative colitis. ACG Case Rep J 2018;5:e28.

63. Lissner D, Glauben R, Allers K, et al. Pulmonary manifestation of crohn's disease developed under treatment with vedolizumab. Am J Gastroenterol 2018;113:1468.

64. Imokawa S, Colby TV, Leslie KO, Helmers RA. Methotrexate pneumonitis: Review of the literature and histopathological findings in nine patients. Eur Respir J 2000;15:373-81.

65. Sostman HD, Matthay RA, Putman CE, Smith GJ. Methotrexate-induced pneumonitis. Medicine (Baltimore) 1976;55:371-88.

66. Grove ML, Hassell AB, Hay EM, Shadforth MF. Adverse reactions to diseasemodifying anti-rheumatic drugs in clinical practice. QJM 2001;94:309-19.

67. Saravanan V, Kelly CA. Reducing the risk of methotrexate pneumonitis in rheumatoid arthritis. Rheumatology (Oxford) 2004;43:143-7.

68. Hilliquin P, Renoux M, Perrot S, Puechal X, Menkes CJ. Occurrence of pulmonary complications during methotrexate therapy in rheumatoid arthritis. $\mathrm{Br} J$ Rheumatol 1996;35:441-5.

69. Bedrossian CW, Sussman J, Conklin RH, Kahan B. Azathioprine-associated interstitial pneumonitis. Am J Clin Pathol 1984;82:148-54. 


\section{Table 1: Classification of pulmonary abnormalities in association with IBD (non-drug} related)

1. Upper Airways

$\circ$ Epiglottitis

- Tracheobronchitis

2. Large airways

- Bronchiectasis

- Acute or chronic bronchitis

3. Small airways
- Bronchiolitis
- Bronchiolitis obliterans

4. Interstitial disease:
- Non-specific interstitial pneumonia
- Acute interstitial pneumonia
- Cryptogenic organizing pneumonia

5. Autoimmune disease:
- Wegener's Granulomatosis
- Pulmonary vasculitis
○ Churg Strauss syndrome

6. Vascular disease
○ Pulmonary embolism

7. Other pulmonary manifestations
○ Necrobiotic nodules
○ Pleuritis
○ Fistulae 


\begin{tabular}{|c|c|c|}
\hline & Patients with GLD $(n=22)$ & Patients with ILD $(n=31)$ \\
\hline Age (years) & $46.4(18-86)$ & $47(17-84)$ \\
\hline Sex & $\begin{array}{c}17 \text { (77.3\%) males : } 5(22.7 \%) \\
\text { females }\end{array}$ & $\begin{array}{l}19(61.3 \%) \text { males : } 12(38.7 \%) \\
\text { females }\end{array}$ \\
\hline Age at diagnosis (years) & $32.2(10-74)$ & $49.65(17-84)$ \\
\hline $\begin{array}{l}\mathrm{CD} / \mathrm{UC} \text { / indeterminate } \\
\text { colitis }\end{array}$ & $17(77.3 \%) / 5(22.7 \%) / 0$ & $8 / 22 / 1$ \\
\hline \multicolumn{3}{|l|}{ Montreal classification } \\
\hline $\mathrm{A} 1 / \mathrm{A} 2 / \mathrm{A} 3$ & $1 / 10 / 6$ & $2 / 5 / 3$ \\
\hline $\mathrm{L} 1 / \mathrm{L} 2 / \mathrm{L} 3$ & $4 / 8 / 5$ & $0 / 7 / 3$ \\
\hline B2 / B2 / B3 & $11 / 5 / 0$ & $7 / 2 / 1$ \\
\hline E1 / E2 / E3 & $0 / 2 / 3$ & $0 / 6 / 17$ \\
\hline Perianal disease & $5(22.7 \%)$ & $4(12.9 \%)$ \\
\hline $\begin{array}{l}\text { Extra-intestinal } \\
\text { manifestations }\end{array}$ & $8(36.4 \%)$ & $11(35.5 \%)$ \\
\hline $\begin{array}{l}\text { Positive family history of } \\
\text { IBD }\end{array}$ & $3(13.6 \%)$ & $4(12.9 \%)$ \\
\hline Previous lung disease & $3(13.6 \%)$ & $11(35.5 \%)$ \\
\hline $\begin{array}{l}\text { Smoking: } \\
\text { current/past/never }\end{array}$ & $\begin{array}{c}3(13.6 \%) / 7(31.8 \%) / 12 \\
(54.5 \%)\end{array}$ & $0 / 10(32.3 \%) / 21(67.7 \%)$ \\
\hline $\begin{array}{l}\text { IBD Activity at event: } \\
\text { active / quiescent }\end{array}$ & $4(18.2 \%) / 18(81.8 \%)$ & $11(35.5 \%) / 20(64.5 \%)$ \\
\hline Drug related lung disease & $8(36.4 \%)$ & $20(64.5 \%)$ \\
\hline $\begin{array}{l}\text { 5-ASA / MTX / } \\
\text { AZA / anti-TNF / } \\
\text { VEDO }\end{array}$ & $0 / 0 / 1 / 6 / 1$ & $9 / 1 / 0 / 9 / 1$ \\
\hline
\end{tabular}

Legend: 5-ASA (5-aminosalicylic acid); MTX (methotrexate); AZA (azathioprine); anti-TNF (anti-tumour necrosis factor); VEDO (vedolizumab) 


\begin{tabular}{|c|c|c|c|c|c|c|c|c|c|c|c|}
\hline Patient & $\begin{array}{l}\text { Age and } \\
\text { Gender }\end{array}$ & $\begin{array}{l}\text { IBD } \\
\text { medications }\end{array}$ & $\begin{array}{l}\text { Duration of } \\
\text { IBD }\end{array}$ & Symptoms & CXR & CT & Bronchoscopy & Biopsy & $\begin{array}{l}\text { Diagnosi } \\
\mathrm{s}\end{array}$ & Steroids & IBD outcome \\
\hline 1 & $21, \mathrm{~F}$ & 5 5ASA & 48 months & $\mathrm{C}, \mathrm{SOB}, \mathrm{T}, \mathrm{L}$ & $\begin{array}{l}\text { Multifocal } \\
\text { opacities and } \mathrm{R} \\
\text { pleural effusion }\end{array}$ & $\begin{array}{l}\text { Bilateral } \\
\text { lymphadenopathy, } \\
\text { multifocal opacities } \\
\text { and R pleural effusion }\end{array}$ & $\begin{array}{l}\text { Extrinsic } \\
\text { compression at } \mathrm{R} \\
\text { lobe due to } \\
\text { Effusion }\end{array}$ & Not done & COP & $\begin{array}{l}\text { Yes, 40mg } \\
\text { several doses } \\
\text { for years }\end{array}$ & $\begin{array}{l}\text { Flare of } \\
\text { disease } \\
\text { requiring IFX }\end{array}$ \\
\hline 2 & $64, \mathrm{M}$ & $\begin{array}{l}\text { ADA 40mg } \\
\text { weekly }\end{array}$ & 51 years & $\mathrm{C}, \mathrm{SOB}$ & opacities & $\begin{array}{l}\text { Bronchial wall } \\
\text { thickening, opacities } \\
\text { in both lobes and } \\
\text { alveolitis }\end{array}$ & $\begin{array}{l}\text { Chronic atrophic } \\
\text { bronchitis }\end{array}$ & $\begin{array}{l}\text { Lymphohist } \\
\text { iocytic } \\
\text { infiltration, } \\
\text { chronic } \\
\text { alveolitis }\end{array}$ & $\begin{array}{l}\text { ILD } \\
\text { Unclassif } \\
\text { ied }\end{array}$ & No & $\begin{array}{l}\text { Adalimumab } \\
\text { started }\end{array}$ \\
\hline 3 & $38, \mathrm{M}$ & 5ASA, AZA & 9 years & C, SOB, L & Opacity R base & $\begin{array}{l}\text { Localised areas of air } \\
\text { shadowing }\end{array}$ & NA & $\begin{array}{l}\text { Organizing } \\
\text { pneumonia } \\
\text { with central } \\
\text { nectrosis }\end{array}$ & $\mathrm{COP}$ & $\begin{array}{l}\text { Yes, } 60 \mathrm{mg} \text { for } \\
3 \text { months, AZA } \\
\text { stopped }\end{array}$ & $\begin{array}{l}\text { Restarted } \\
\text { AZA } \\
\text { Quiescent } \\
\text { disease }\end{array}$ \\
\hline 4 & $20, \mathrm{M}$ & $\begin{array}{l}\text { Vedolizumab } \\
\text { 300mg } 8 \\
\text { weekly }\end{array}$ & 6 Years & $\mathrm{C}, \mathrm{T}, \mathrm{L}$ & $\begin{array}{l}\text { Bronchial wall } \\
\text { thickening }\end{array}$ & $\begin{array}{l}\text { Bilateral basal } \\
\text { bronchiectasis }\end{array}$ & NA & NA & $\mathrm{COP}$ & No & Quiescent \\
\hline 5 & $67, \mathrm{M}$ & Nil & NA & $\mathrm{C}$ & $\begin{array}{l}\text { Interstitial lung } \\
\text { pattern }\end{array}$ & $\begin{array}{l}\text { Tree in bud pattern in } \\
\mathrm{R} \text { lobe }\end{array}$ & Normal & Not done & $\begin{array}{l}\text { ILD } \\
\text { Unclassif } \\
\text { ied }\end{array}$ & $\begin{array}{l}\text { Yes } 5 \mathrm{mg} \text { for } \\
\text { years }\end{array}$ & $\begin{array}{l}\text { Flare of } \\
\text { disease, } \\
\text { required IFX } \\
\text { and steroids }\end{array}$ \\
\hline 6 & $65, \mathrm{M}$ & 5ASA, AZA & 27 Years & $\mathrm{C}, \mathrm{SOB}$ & $\begin{array}{l}\text { Bilateral } \\
\text { interstitial } \\
\text { abnormalities }\end{array}$ & $\begin{array}{l}\text { Honeycombing with } \\
\text { reticular opacities }\end{array}$ & NA & NA & IPF & No & Quiescent \\
\hline 7 & $58, \mathrm{M}$ & $5 \mathrm{ASA}$ & 8 Years & $\mathrm{C}, \mathrm{SOB}$ & $\begin{array}{l}\text { Streaky } \\
\text { consolidation }\end{array}$ & $\begin{array}{l}\text { Bilateral } \\
\text { bronchopneumonia } \\
\text { with R pleural } \\
\text { effusion }\end{array}$ & Normal & $\begin{array}{l}\text { Cryptogeni } \\
\text { c } \\
\text { organizing } \\
\text { pneumonia }\end{array}$ & COP & $\begin{array}{l}\text { Yes } 7.5 \mathrm{mg} \text { for } \\
1 \text { year, AZA } \\
\text { stopped, } \\
\text { required BIPAP } \\
\text { FOR } 1 \text { month }\end{array}$ & Quiescent \\
\hline
\end{tabular}




\begin{tabular}{|c|c|c|c|c|c|c|c|c|c|c|c|}
\hline 8 & $58, \mathrm{M}$ & Nil & 23 Years & $\mathrm{C}, \mathrm{SOB}, \mathrm{L}$ & & Hyperinflated lungs & Normal & $\begin{array}{l}\text { Constrictiv } \\
\text { e obliterans } \\
\text { pneumonia } \\
\text { with } \\
\text { microgranu } \\
\text { loma }\end{array}$ & $\begin{array}{l}\text { ILD } \\
\text { Unclassif } \\
\text { ied }\end{array}$ & $\begin{array}{l}\text { Yes, } 60 \mathrm{mg} \text { for } 1 \\
\text { year }\end{array}$ & $\begin{array}{l}\text { Flare of IBD } \\
\text { with stenosis } \\
\text { and high } \\
\text { grade } \\
\text { dysplasia } \\
\text { treated with } \\
\text { steroids and } \\
\text { surgery }\end{array}$ \\
\hline 9 & $50, \mathrm{M}$ & 5ASA & 3 Years & $\mathrm{C}, \mathrm{SOB}, \mathrm{T}, \mathrm{L}$ & $\begin{array}{l}\text { bilateral small } \\
\text { area shadowing }\end{array}$ & $\begin{array}{l}\text { Mediastinal } \\
\text { lymphadenopathy, } \\
\text { central accented } \\
\text { alveolar shadowing } \\
\text { and pleural effusion }\end{array}$ & $\begin{array}{l}\text { Bilateral } \\
\text { inflammation with } \\
\text { hypersecretion and } \\
\text { mucous }\end{array}$ & $\begin{array}{l}\text { Cryptogeni } \\
\text { c } \\
\text { organizing } \\
\text { pneumonia }\end{array}$ & $\mathrm{COP}$ & No & $\begin{array}{l}\text { Flare of IBD } \\
\text { with } \\
\text { pyoderma } \\
\text { gangrenosum } \\
\text { and Sweet } \\
\text { syndrome } \\
\text { requiring IFX } \\
\text { and steroids, } \\
\text { then switched } \\
\text { to golimumab } \\
\text { and } \\
\text { tacrolimus }\end{array}$ \\
\hline 10 & $70, \mathrm{M}$ & $\begin{array}{l}\text { 5ASA, AZA, } \\
\text { Steroids }\end{array}$ & 16 Months & SOB & NA & $\begin{array}{l}\text { Septal thickening and } \\
\text { reticular changes in } \\
\text { upper lobes, } \\
\text { honeycomb }\end{array}$ & NA & Not done & IPF & Yes, 2Omg & $\begin{array}{l}\text { Flare of } \\
\text { disease } \\
\text { requiring } \\
\text { steroids }\end{array}$ \\
\hline 11 & $57, \mathrm{M}$ & Steroids & 14 Years & $\mathrm{C}, \mathrm{SOB}$ & NA & $\begin{array}{l}\text { UIP Pattern, } \\
\text { mediastinal } \\
\text { lymphadenopathy }\end{array}$ & $\begin{array}{l}\text { Purulent bronchitis } \\
\text { with inflammation }\end{array}$ & $\begin{array}{l}\text { Honeycom } \\
\text { b interstitial } \\
\text { pneumonia } \\
\text { with } \\
\text { fibrosis }\end{array}$ & IPF & Yes, 60mg & NA \\
\hline
\end{tabular}

$\mathrm{C}=$ cough, $\mathrm{SOB}=$ Shortness of breath, $\mathrm{T}=\mathrm{Fever}, \mathrm{L}=$ lethargy

$\mathrm{COP}=$ Cryptogenic organizing pneumonia, IPF= Idiopathic pulmonary fibrosis, ILD =Interstitial lung disease 
Supplementary Table 2: Biologic related ILD cases and IBD outcome

$$
\text { Infliximab }
$$

\begin{tabular}{|c|c|c|c|c|c|c|c|c|c|c|c|}
\hline Patient & $\begin{array}{l}\text { Age } \\
\text { and } \\
\text { Gender }\end{array}$ & $\begin{array}{l}\text { IBD } \\
\text { medications }\end{array}$ & $\begin{array}{l}\text { Duration of } \\
\text { infliximab }\end{array}$ & Symptoms & CXR & CT & Bronchoscopy & Biopsy & Diagnosis & Steroids & IBD outcome \\
\hline 1 & $23, \mathrm{~F}$ & 5ASA & 6 doses & C,SOB, & Normal & $\begin{array}{l}\text { Bilateral shadowing } \\
\text { and interstitial } \\
\text { thickening }\end{array}$ & Normal & $\begin{array}{l}\text { mild chronic non } \\
\text { specific non } \\
\text { granulomatous } \\
\text { infiltrated }\end{array}$ & IPF & $\begin{array}{l}\text { Yes, } 50 \mathrm{mg} \\
7 \text { days then } \\
25 \mathrm{mg} \text { for } \\
14 \text { days } \\
\text { with steroid } \\
\text { inhaler }\end{array}$ & $\begin{array}{l}\text { Mild symptoms } \\
\text { started 5ASA }\end{array}$ \\
\hline 2 & $43, \mathrm{M}$ & $5 \mathrm{ASA}$ & 9 doses & $\mathrm{C}, \mathrm{SOB}$ & Normal & $\begin{array}{l}\text { Bilateral shadowing } \\
\text { and interstitial } \\
\text { thickening }\end{array}$ & Normal & $\begin{array}{l}\text { mild chronic non } \\
\text { specific non } \\
\text { granulomatous } \\
\text { infiltrated }\end{array}$ & IPF & $\begin{array}{l}\text { Yes, } 50 \mathrm{mg} \\
\text { for } 10 \text { days } \\
\text { then } 25 \mathrm{mg} \\
\text { for } 20 \text { days } \\
\text { with } \\
\text { inhalers }\end{array}$ & Quiescent \\
\hline 3 & $16, \mathrm{M}$ & Nil & 7 doses & C,SOB,L & Normal & $\begin{array}{l}\text { Diffuse } \\
\text { bronchiectasis }\end{array}$ & $\begin{array}{l}\mathrm{R} \text { middle lobe } \\
\text { inflammation }\end{array}$ & Not done & COP & No & $\begin{array}{l}\text { Active disease } \\
\text { had } \\
\text { Proctocolectom } \\
\text { y and after } \\
\text { surgery had } \\
\text { vedolizumab for } \\
\text { pouchitis and } \\
\text { MTX }\end{array}$ \\
\hline
\end{tabular}

\begin{tabular}{|c|c|c|c|c|c|c|c|c|c|c|c|}
\hline 4 & $71, \mathrm{M}$ & 5ASA & 6 doses & SOB,T,L & $\begin{array}{l}\text { Opacities } \\
\text { superior and } \\
\text { middle lobe }\end{array}$ & $\begin{array}{l}\text { Diffuse } \\
\text { centrilobular, } \\
\text { paraseptal } \\
\text { emphysema with } \\
\text { interlobular septal } \\
\text { thickening and } \\
\text { ground glass } \\
\text { opacities }\end{array}$ & Normal & Not done & $\begin{array}{l}\text { ILD } \\
\text { unclassified }\end{array}$ & $\begin{array}{l}\text { Yes, } \\
1 \mathrm{mg} / \mathrm{kg} / \text { day } \\
\text { slow } \\
\text { tapering }\end{array}$ & $\begin{array}{l}\text { Ongoing } \\
\text { symptoms } \\
\text { started AZA }\end{array}$ \\
\hline 5 & $45, \mathrm{~F}$ & MTX & NA & SOB,L & $\begin{array}{l}\text { bilateral basal } \\
\text { pneumonia }\end{array}$ & $\begin{array}{l}\text { Bilateral basal } \\
\text { pneumonia }\end{array}$ & Normal & Not done & COP & $\begin{array}{l}\text { Yes, 50mg } \\
\text { Daily } \\
\text { Ongoing }\end{array}$ & $\begin{array}{l}\text { Flare of disease } \\
\text { started } \\
\text { Ustekinumab }\end{array}$ \\
\hline
\end{tabular}




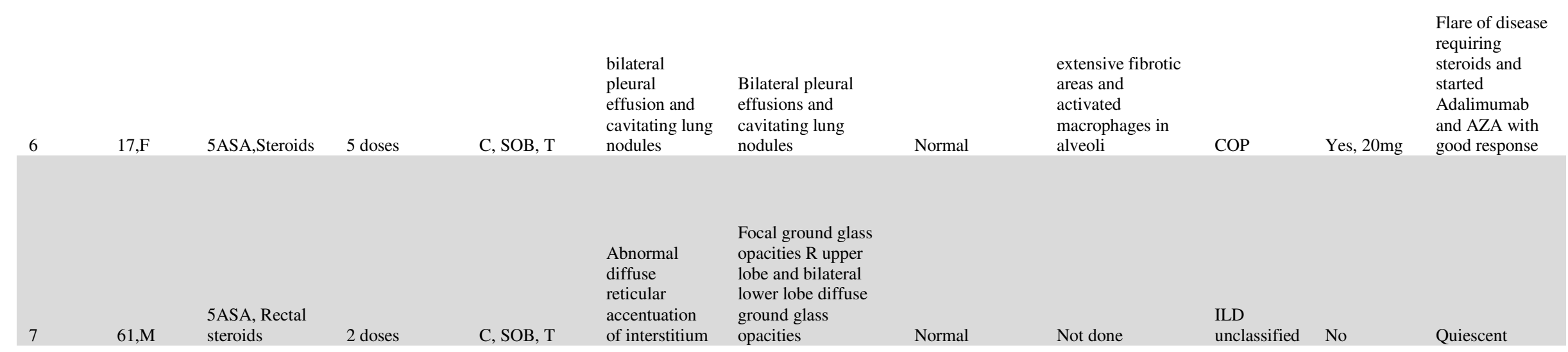

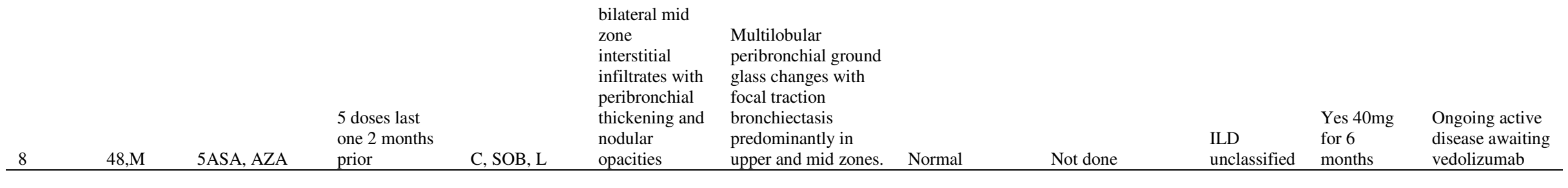

Golimumab 


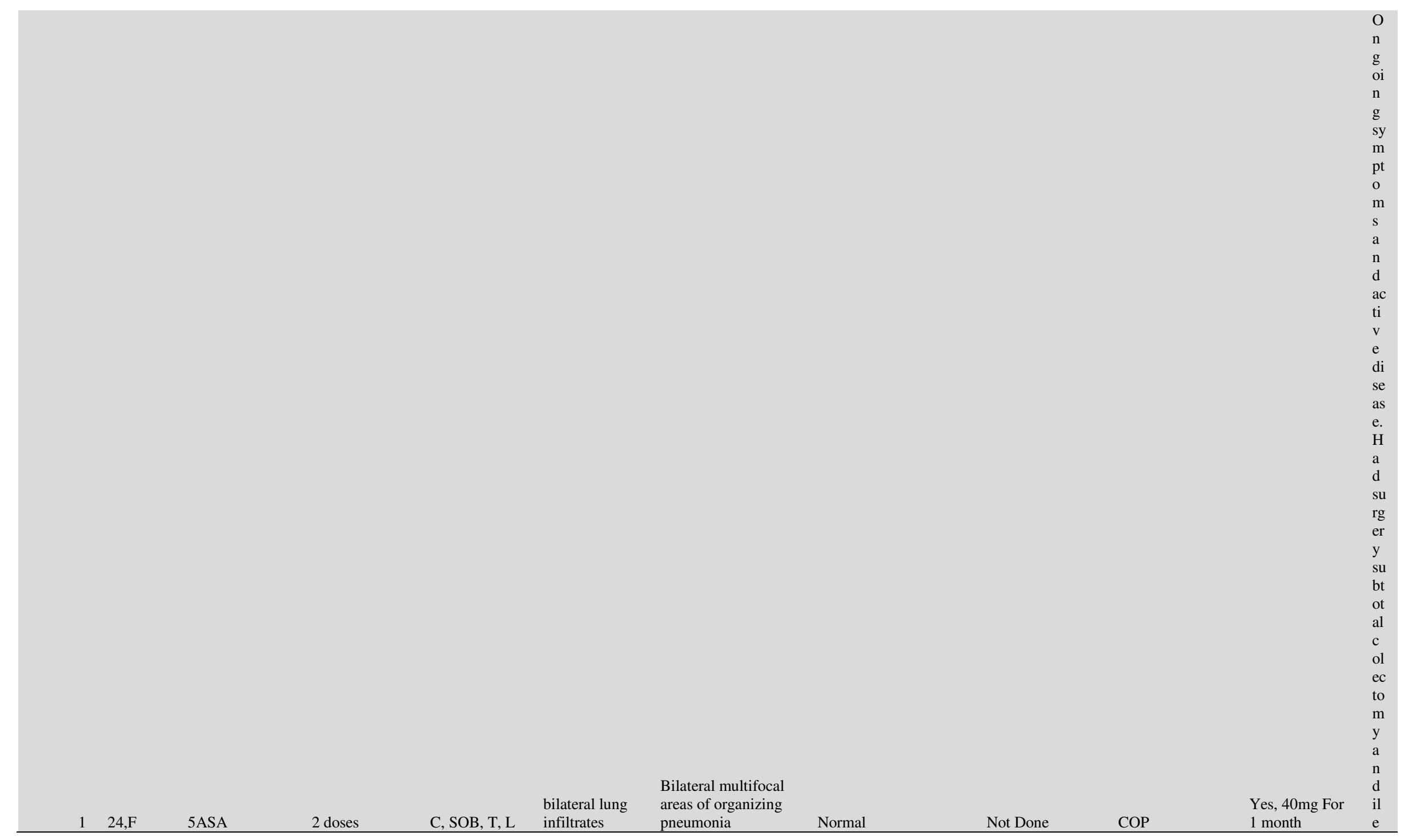




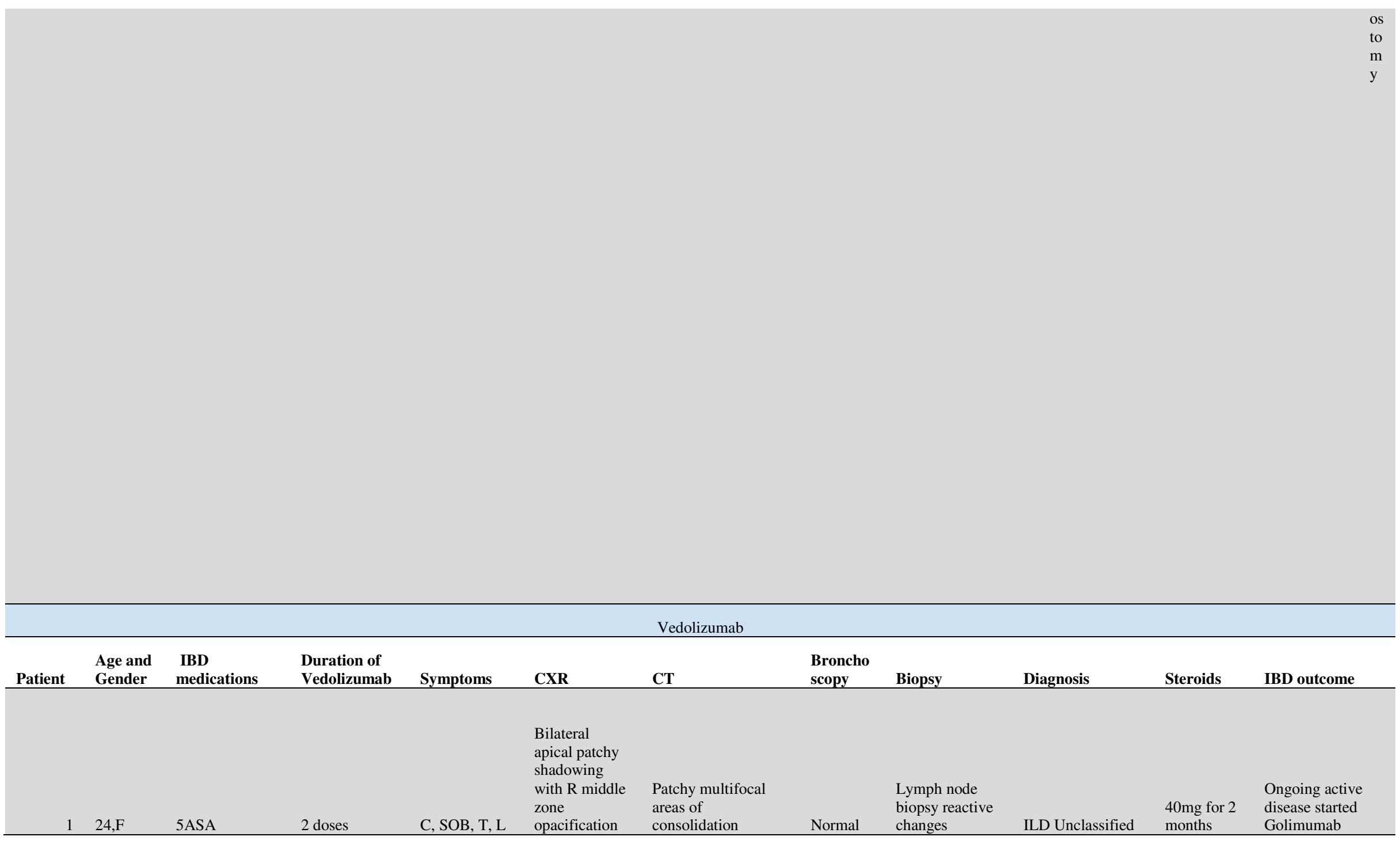





\begin{tabular}{|c|c|c|c|c|c|c|c|c|c|c|c|}
\hline Patient & $\begin{array}{l}\text { Age and } \\
\text { Gender }\end{array}$ & $\begin{array}{l}\text { IBD } \\
\text { medications }\end{array}$ & $\begin{array}{l}\text { Duration of } \\
\text { 5ASA and } \\
\text { dosage }\end{array}$ & Symptoms & CXR & CT & Bronchoscopy & Biopsy & Diagnosis & Steroids & IBD outcome \\
\hline 1 & $66, \mathrm{~F}$ & $\begin{array}{l}\text { Previous AZA } \\
\text { and IFX }\end{array}$ & $3 \mathrm{gr}$ for 14 years & $\mathrm{SOB}, \mathrm{T}$ & $\begin{array}{l}\text { R pleural } \\
\text { effusion } \\
\text { and } \\
\text { inflamma } \\
\text { tory } \\
\text { changes }\end{array}$ & $\begin{array}{l}\text { tumour R } \\
\text { lung with } \\
\text { inflammato } \\
\text { ry changes }\end{array}$ & Normal & $\begin{array}{l}\text { Bronchiolitis } \\
\text { obliterans } \\
\text { with non } \\
\text { caseating } \\
\text { granulomas }\end{array}$ & $\mathrm{COP}$ & Yes months & $\begin{array}{l}\text { One flare treated } \\
\text { with steroids }\end{array}$ \\
\hline 2 & $26, \mathrm{~F}$ & $\begin{array}{l}\text { Budesonide, } \\
\text { Previous AZA }\end{array}$ & 3gr NA & $\mathrm{C}, \mathrm{T}$ & $\begin{array}{l}\text { Focal } \\
\text { lesions } \\
\text { upper } \\
\text { lobes }\end{array}$ & $\begin{array}{l}\text { Irregular } \\
\text { band-like } \\
\text { nodular } \\
\text { areas in } \\
\text { both lungs } \\
\text { with pleural } \\
\text { effusions }\end{array}$ & NA & Not done & ILD Unclassified & Pt refused & Restarted 5ASA \\
\hline 3 & $18, \mathrm{M}$ & Nil & 3gr 10 months & $\mathrm{C}$ & $\begin{array}{l}\text { Shadows } \\
\text { in apex } \\
\text { of } r \text { lung }\end{array}$ & $\begin{array}{l}\text { sub- } \\
\text { pleurotic } \\
\text { area of } \\
\text { fibrosis }\end{array}$ & $\begin{array}{l}\text { large white } \\
\text { submucosal } \\
\text { nodules in } \\
\text { trachea and } \mathrm{R} \\
\text { main bronchus }\end{array}$ & $\begin{array}{l}\text { fibropurulent } \\
\text { masses with } \\
\text { inflammatory } \\
\text { cell and } \\
\text { squamous } \\
\text { metaplasia }\end{array}$ & $\mathrm{COP}$ & $\begin{array}{l}\text { Yes methyl } \\
\text { prednisolone } \\
32 \mathrm{mg} \text { long } \\
\text { term }\end{array}$ & \\
\hline 4 & $20, \mathrm{M}$ & Nil & $1.5 \mathrm{gr}$ for 7 years & $\mathrm{C}, \mathrm{SOB}, \mathrm{T}$ & $\begin{array}{l}\text { Bilateral } \\
\text { infiltrates } \\
\text { in } \\
\text { posterior } \\
\text { basal } \\
\text { lobes }\end{array}$ & $\begin{array}{l}\text { Bronchioliti } \\
\text { s obliterans } \\
\text { organizing } \\
\text { pneumonia }\end{array}$ & Normal & Not done & $\mathrm{COP}$ & $\begin{array}{l}\text { Yes, } 20 \mathrm{mg} \\
\text { for } 1 \mathrm{month}\end{array}$ & $\begin{array}{l}\text { Pt started on IFX } \\
5 \text { years later }\end{array}$ \\
\hline 5 & $61, \mathrm{M}$ & Nil & 3 gr for 3 years & $\mathrm{C}, \mathrm{SOB}, \mathrm{T}$ & $\begin{array}{l}\text { Basal } \\
\text { infiltrates }\end{array}$ & $\begin{array}{l}\text { Bilateral } \\
\text { alveolar } \\
\text { infiltrates }\end{array}$ & Normal & Not done & ILD Unclassified & $\begin{array}{l}\text { Yes } 50 \mathrm{mg} \text { for } \\
3 \text { months }\end{array}$ & Quiescent \\
\hline
\end{tabular}




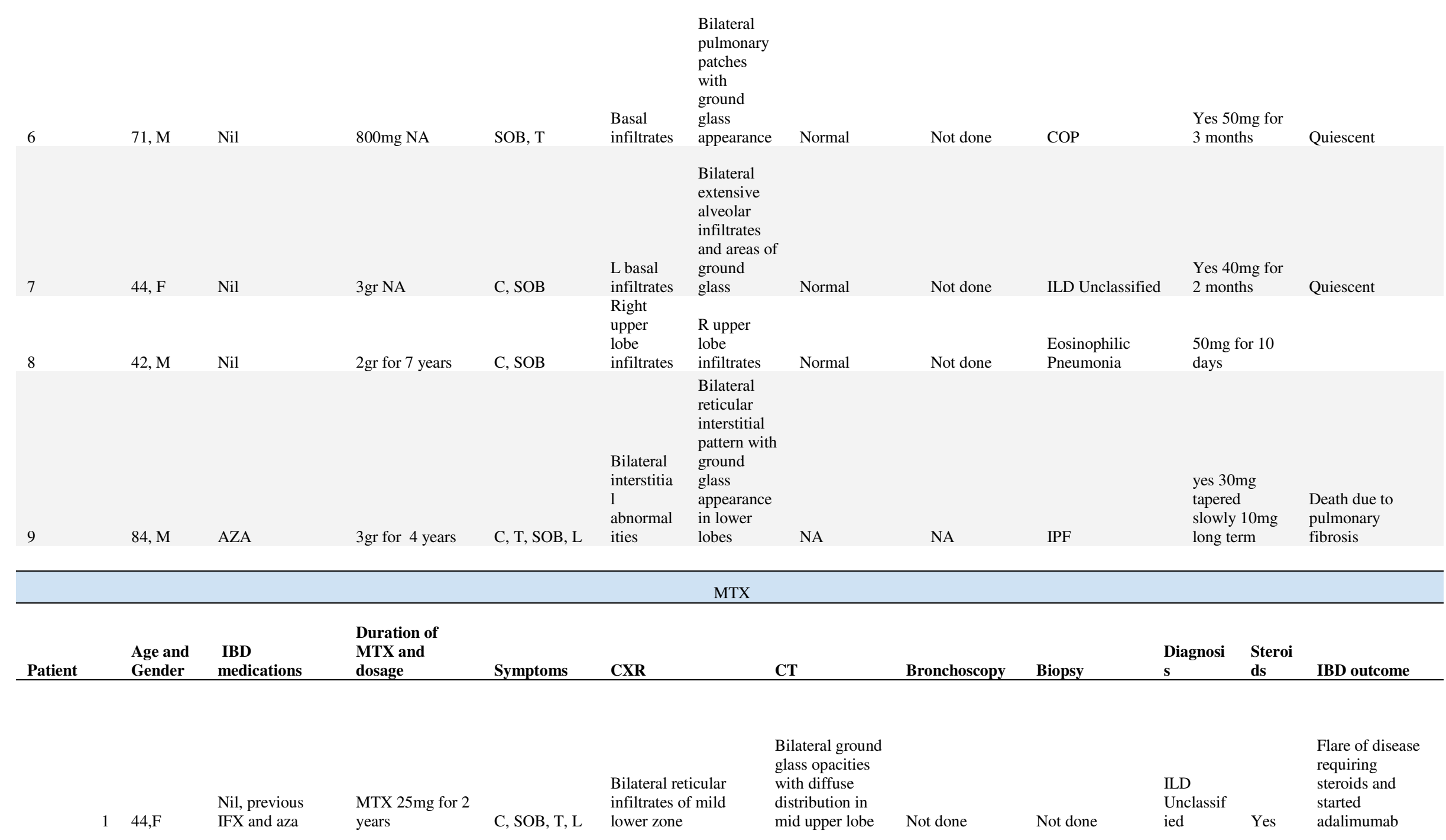


Figure Legends

Figure 1: Characteristics and respiratory outcomes of ILD related to IBD (non- and drug-related) in our cohort.

Figure 2: Characteristics and respiratory outcomes of GLD related to IBD (non- and drug-related) in our cohort. 